\title{
EU principles as a guide for modelling timely administrative procedures in Slovenia and Croatia
}

\author{
Tina Sever en Polonca Kovac
}

\begin{abstract}
Aanbevolen citeerwijze bij dit artikel
Tina Sever en Polonca Kovac, 'EU principles as a guide for modelling timely administrative procedures in Slovenia and Croatia', NALL maart 2016, DOI: 10.5553/NALL/.000024
\end{abstract}

\section{A Introduction}

In guaranteeing protection of the parties and public interest in the sense of legal certainty and predictability, the enactment of administrative procedures (hereinafter APs) is the first precondition for efficient administrative decision-making and work of public administration (hereinafter PA) in general. The content and the drafting technique of such regulation must, however, evolve in line with the development of the society and its needs. The codification of APs - usually by means of a general act on APs (hereinafter APA) or PA - enables the reduction of burdens for users and organizations and the consolidation of the rule of law, which in turn positively affects economic development. ${ }^{\mathbf{1}}$ European countries have a long tradition of codification of APs. Roughly four traditions of administrative law can be distinguished, each presenting its own method and content of codification $^{2}$ : the French administration-centred tradition, the Anglo-Saxon individual-centred tradition, the Scandinavian ombudsman-centred tradition and the most broadly applied German-Austrian legislaturecentred tradition of the Rechtsstaat. The public law determinant in PA and APs in continental and Eastern Europe ${ }^{\mathbf{3}}$ also influences supranational (EU) public policies.

In the above context, AP is most often understood as the basic formalprocedural framework to enforce administrative rights, legal interests and obligations (determined by substantive public law, i.e. sector-specific acts) in the relations with individuals and legal entities. Depending on its legal regulation and understanding, AP can serve as a basic dialogue tool between PA and its clients, i.e. users of public services and parties in administrative procedures, enabling a partnership-based development of the society. A holistic regulation of APs should thus pursue two goals. First, implementation of public policies by means of protection of public interest pursuant to sector-specific laws, and, second, legal protection of weaker 
parties in their relations with the authorities. Recently, however, under the influence of modern theories of good governance and good (proper, sound) administration, the vast majority of comparable (European) countries (e.g. France in 2015) ${ }^{4}$ as well as the EU itself ${ }^{5}$ have been turning the relevant regulation into a legally defined and politically-sociologically driven societal process. The European Parliament follows a similar trend in an attempt to draft the EU APA as the single legal instrument to be applied at the level of the EU institutions. ${ }^{\mathbf{6}}$

This article makes a normative and, to some extent, empirical analysis of Slovene and Croatian regulations, using country profiles as a case study for any German-oriented administrative framework. The article focuses on the following research questions: do Slovene and Croatian APAs comply with the EU principles as formulated recently, and if so, in which elements in particular? Is there a key difference between Slovene and Croatian law? Which institutions should be redefined in Slovenia and Croatia to follow the EU procedural standards? To address these questions, the article is structured in several parts presenting the results of several research methods applied.

First, an introduction to legal principles is presented, followed by a general analysis of the role of APs (and APAs) to explore them as an instrument of good administration. In this part, further normative analysis of APAs in Slovenia and Croatia in the light of efficient and user-oriented administrative decision-making in the EU is applied. Particular emphasis is laid on a principle that has been gaining considerable importance in theory, regulation and case law, namely the right to have one's affairs handled within a reasonable time, which is a component of fair trial or good administration (see Articles 6 and 13 of the ECHR and Articles 41 and 47 of the Charter of Fundamental Rights of the EU (EU Charter, 2010/C 83/02)). Second, based on gaps found between the Slovene and the Croatian APAs, on the one hand, and the EP's Resolution, on the other, the article proceeds to elaborate suggestions and recommendations for de lege ferenda regulation. Application of mixed, namely dogmatic-normative and historical-comparative methods, is used as a ground for formulating a draft model of accelerative and braking elements to ensure a balanced protection of fundamental APs principles and design the relevant improvements. Finally, initial research questions are answered and some concluding remarks put forward.

\section{B. Analysis of APs and APAs as instruments of good administration}

\section{Importance and selected aspects of good administration in the EU in view of national APAs}

\section{I.I. Aim and scope of fundamental (administrative) legal principles}

European administrative law evolved from non-written general legal principles common to the constitutional (administrative) traditions of the Member States. Over time, a reverse effect was observed, with the EU law influencing national legislations. The core principles of the existing 
European administrative law include proportionality, legal certainty, protection of acquired rights, non-discrimination, fair administrative procedure and efficient judicial review - all standards of modern administrative law common to the Member States.7

Typically, administrative legal principles deriving from APAs operationalize constitutional principles and express the purpose of the procedure. ${ }^{\mathbf{8}}$ Most APAs provide - with regard to the basic principles and rights related to good administration and safeguards of the Rechtsstaat - that special regulations supersede the general APA, yet the basic principles should be regarded as the minimum standard (the de minimis rule). That is, principles promote an ideal state of affairs and set the legally relevant purpose to be followed. ${ }^{9}$ Usually, the constitution is a source of fundamental values valid for a certain society, which are also expressed through fundamental constitutional principles. These are legal ground for lower acts to follow, when enacting principles and rules. However, not all principles are precisely defined by law (e.g. the Slovene Constitution does not explicitly define the principle of proportionality, but the latter was derived from the Constitutional Court's case law interpretation on the rule of law). Unlike legal rules, which precisely define the way of behaviour and conduct, principles give only value-based criteria for our behaviour, but in a way that is more flexible. Therefore, principles are not absolute in their content, but present a value base, which requires "proportional behaviour" and "right rate". Their use and definition of "right rate" differ with each individual case. ${ }^{\mathbf{1 0}}$

Finally, even though some principles are recognized before enactment only by common legal tradition and case law, that does not diminish their relevance. The legislature will decide whether there is a need to codify certain principles, depending on the state of society and policies followed in a particular time and space. We do think the codified principles and rules make it easier for the courts and parties to refer to them, preventing abuses. ${ }^{11}$ In cases where principles are not explicitly regulated, the courts and parties might be more flexible in regard to their use and referral to them, creating a less rigid environment. However, this can mean a certain level of uncertainty for the parties as to whether the court will recognize the use of certain principles in a particular case. ${ }^{\mathbf{1 2}}$

\section{I.II. Regulation of the right to good administration in EU}

Following the criticism of Weber's model of hierarchical administration, the past decades saw a gradual transition to participative and open public administration and the introduction of private principles and methods of work in the public sector. In the late 1980s, a new concept of public management known as the New Public Management (NPM) evolved, stressing management efficiency, democracy and user-orientation. Although to a different extent and in different forms, numerous countries introduced NPM principles, such as privatization, decentralization, deregulation, new forms of accountability and performance measurement. ${ }^{\mathbf{1 3}}$ Theory and practice gave rise to a doctrine that is in partial contrast to NPM, i.e. the doctrine of good governance. The latter is related to the principle of orientation towards the users of public services (transition from authoritative and centralized actions to service-based, decentralized and 
participative operation of the State). According to this doctrine, the State merely provides authority and protects general social benefit, but is not the exclusive and primary holder of authority. The State thus aims at promoting consensual solutions, proportionate to public interest. The model of good governance as strategic partnership management of public affairs is also the basis for the third generation of administrative procedures (late 20th century and present time), as defined by Barnes. ${ }^{\mathbf{1 4}}$ A part of the good governance doctrine is the right to good administration, which is a narrower legal concept based on procedural rights. This enables creative partnerships between social groups and, consequently, greater legitimacy of public policies and authoritative decisions. ${ }^{\mathbf{1 5}}$

As regards the regulation of the concept of good administration in the EU, of particular importance is Article 41 of the EU Charter, ${ }^{\mathbf{1 6}}$ a binding legal document, i.e. primary legislation, since 2010. Formally, the EU Charter and the (draft) EU APA are restricted to the EU institutions and do not apply to the Member States, ${ }^{\mathbf{1 7}}$ unless they are implementing Union law (Article 51 of the EU Charter). ${ }^{\mathbf{1 8}}$ However, through case law these acts can also have a broader convergence effect at the national level. ${ }^{19}$ That is, considering the convergent development of administrative law and codification of the EU-related documents on the level of principles, these principles and rights can well serve as a reference for the (modern) national codification of APs or as an example of good practice for other entities (»spillover effect «). ${ }^{\mathbf{2 0}}$ This effect is especially evident when case law supports normative codification as by the Court of Justice of the EU (CJEU) in cases Tillak in 2006 or H. N. in 2014, although the role of the CJEU in this sense is rather reserved. ${ }^{\mathbf{2 1}}$ The implications of the CJEU case law are of utmost importance to Member States, primarily to new ones such as Slovenia and Croatia, owing to nationally underdeveloped theory and jurisprudence on good administration, in general, and its elements such as timeliness, in particular (see further case law of the ECHR regarding Slovene and Croatian cases (see footnotes 29-30)).

The right to good administration or, more appropriately, the fundamental principles of administrative law as a set of rights of good administration in accordance with Article 41 of the EU Charter, ${ }^{\mathbf{2 2}}$ call for fair and impartial handling of affairs within a reasonable time and includes the right to be heard, ${ }^{\mathbf{2 3}}$ to have access to one's file, to use any official language of the EU, to have the Union make good any damage, and the obligation to state reasons for all decisions. In order to make good administration more concrete, the European Code of Good Administrative Behaviour was adopted. ${ }^{\mathbf{2 4}}$ The EU Code includes classic institutions such as the rule of law, proportionality, impartiality, the right to be heard, access to information, the duty to state the grounds of decisions, and indication of remedies, as well as modern principles of participation, transparency, efficiency and reasonable time limit (Article 17). Several acts in this regard were also adopted by the Council of Europe (CoE), above all various recommendations (e.g. $\operatorname{Rec}(2004) 6,(2007) 7,(2004) 20,(2010) 13$ on improvement of domestic remedies, good administration, judicial review of administrative acts, efficient remedies for excessive length of proceedings, etc.). ${ }^{25}$ In this respect, in case of violations of fair and impartial handling of affairs within reasonable time Member States can be prosecuted before the European Court of Human Rights (e.g. ECtHR cases on duration of 
procedures Kudla v. Poland ${ }^{\mathbf{2 6}}$; Lukenda or Mandić et al. v. Slovenia ${ }^{\mathbf{2 7}}$; Počuča, Božić or Štokalo \& others v. Croatia ${ }^{28}$ ).

As a result, the implementation of common fundamental principles of good administration in fact leads to the harmonization of administrative decision-making systems or even APs in the EU Member States and contributes to a further development of the European Administrative Space. ${ }^{\mathbf{2 9}}$ At the national level, similar principles and rights are enshrined, for instance, in the Slovene legislation concerning decisions in administrative matters, as derived from the basic principles and rules under APA and other (systemic) regulations relevant for PA. ${ }^{\mathbf{3 0}}$ Mostly on national level regulation, the tendency is to codify principles as part of general provisions at the beginning of the APA, i.e. introductory and general provisions, since they are valid throughout the administrative procedure. E.g. Slovene APA (1999) - general provisions: Articles 6-14; Croatian APA (2009) - general provisions: Articles 5-14; Czech Administrative Procedure Code (2004) - introductory provisions: Sections 2-8; Estonian APA (2001) - general provisions: Sections 3-7; Finnish APA (2003) - general provisions: sections 6-10 etc. That is, fundamental principles ensure minimum procedural standards and serve as guidelines and interpretative tools valid throughout the administrative procedure. Their aim is to resolve procedural dilemmas in cases where law does not precisely define certain real-life situations and does not give straight answers and solutions to certain procedural dilemmas. Moreover, fundamental principles include basic values as promoted by the APA, showing the state of mind of society and level of cultural development in PA. Therefore, there are certain differences among the national APA with regard to the content of the principles. Besides the usual classical principles, such as principle of legality and impartiality, modern AP codifications also include modern managerial principles such as customer-oriented public administration (e.g. Czech Code, Section 4/1: "public administration is a service to public"; cf. also Finnish APA, section 7: "Service principle and appropriateness of service"); mutual cooperation of administrative authorities in the interest of good administration (Czech Code, Section 8/2), etc. ${ }^{\mathbf{3 1}}$

\section{I.III. Administrative procedure codification in EU, especially Slovenia and Croatia}

In the past, Slovenia and Croatia had been part of the same country; they both became independent in 1991 and are now members of the EU and signatories of the European Convention on Human Rights (ECHR). The Slovene and Croatian APAs (Zakon o splošnem upravnem postopku (General Administrative Procedure Act), Official Gazette of the Republic of Slovenia No. 80/99 and amendments; Zakon o općem upravnom postupku (General Administrative Procedure Act), Official Gazette of the Republic of Croatia No. 47/09, co-financed by the EU under the CARDS 2003 project) were modelled on the Yugoslav law. The latter (adopted as early as 1956 and amended four times) was based on the Austrian model (1925) and was considered one of the most comprehensive in the world. ${ }^{\mathbf{3 2}}$ Such a long tradition - relying on the thesis that AP regulation implies democracy as well as the awareness that codification is important for the functioning of the society and the administrative system, particularly in the sense of 
protection of public interest and of the rights of the parties - can indeed be evaluated as positive. Some European countries, for instance, enacted AP only in the 1990s or later (e.g. Italy (1990), Netherlands (1994), Lithuania (1999) ${ }^{33}$ and France (2015)). Today, the majority of the EU countries have an APA, while others have at least some kind of codes, e.g. Romania and Ireland.

In what follows an overview is presented of traditional Slovene APA and the significantly modernized Croatian APA, ${ }^{34}$ compared with the principles and key rules of the EP's Resolution or "the EU APA" (2013). The EU APA includes six recommendations, whereby Recommendation 3 defines nine general principles and Recommendation 4 ten rules, most of them as rights of a principle nature. ${ }^{35}$ Legal protection is specified in Recommendation 5 . Given the dogmatically inconsistent yet equivalent nature of the principles and basic rights enshrined in the EU APA, both are treated as equal, i.e. the rules that are sovereign rights (e.g. reasoning or legal protection) and are not repeated in the form of principles (e.g. impartiality) are considered principles themselves. Such intertwining is a proof that procedural standards of good administration as a basic human right are the core value and a legal and ethical principle, i.e. a guideline and a rule.

At the level of national APAs, only fundamental principles are analysed (Art. 5-14 of the Croatian APA and Art. 6-14 of the Slovene APA), accompanied by the constitutional guarantees of the two countries. We believe, in fact, that defining the elements of good administration as principles enshrined in national laws or even in the Constitution sufficiently complies with the purpose and level of EU standards. A further distinction is made between traditional/classical principles, rights and principles typical of modern good governance (Table 1). In the Table, X stands for indirectly or only abstractly (without exact upgrading of rules) defined principles or (only) part of another principle. XX stands for specifically emphasized (i.e. fully respected) principles or rights in recent codification. $\mathrm{Xx}$ represents the in-between state of affairs (more than $\mathrm{X}$ but less than $\mathrm{XX}$ ). The order of the elements depicts the development moment. The first principle to be introduced in EU APA is the principle of lawfulness. Similarly, the same pattern is also introduced at the national level. This order is logical since the principle of lawfulness provides the legal basis for all administrative action. It requires EU administration to apply rules and procedures laid down in EU legislation and to act in accordance with law. Furthermore, administrative powers should be based on the law, and decisions or measures should not be arbitrary, but based on the law or motivated by the public interest. Second on the "list" is the principle of nondiscrimination and equal treatment, requiring avoidance of any unjustified discrimination between persons. Similar situations should be treated in the same manner and differences in treatment justified by objective characteristics. The third is the principle of proportionality, giving power to the EU administration to take decisions, which affect the rights and interests of individuals only when necessary and only to the extent enabling achievement of the pursued aim. Officials need to ensure a fair balance between the interests of private persons and the general interest and shall not impose excessive burdens (administrative or economic) in relation to the expected benefit. In accordance with the principle of impartiality, the EU administration needs to be impartial and independent, meaning 
arbitrary and preferential treatment is prohibited, and all actions should pursue the EU interest and the public good. Finally, no action should be based on any kind of pressure (personal, family, national or political), and a fair balance should be guaranteed among different citizens' interests. Furthermore, the principle of consistency and legitimate expectations requires the $\mathrm{EU}$ administration to be consistent in its actions and ensure normal administrative practice, which should be publicly known. If legitimate ground for a different practice exists in an individual case, reasons for such practice should be given. Legitimate and reasonable expectations of persons should be respected. Moreover, the EU administration should respect persons' privacy. However, in accordance with the principle of transparency, the EU administration needs to be open, document administrative procedures and keep an adequate record of actions, as well as allow access to documents as defined by EU regulation. To establish confidence and predictability in relations between individuals and administration, the principle of fairness must be respected. Finally, EU administration actions should be governed by the criteria of efficiency and public service, advising the public on the way the matter is going to be pursued. In the case of matters falling out of their competence, persons should be directed to approach the competent authority.

Based on the given content of all nine principles and compared with Slovene and Croatian regulation, we can draw the following conclusions (see Table 1). First, the content of the principles of lawfulness, nondiscrimination and equal treatment is the same, which is not surprising, given they protect fundamental values, recognized in democratic societies. Similarly, the principle of proportionality follows the same logic also at the national level in its first part, although it is less emphasized in Slovene APA as only part of the principle of rights protection. However, EU APA also explicitly refers to avoiding administrative and economic burdens when making decisions. The latter is not included in Croatian or Slovene APA, but "only" emphasized in terms of better law making.

Other differences we can highlight for Slovenia concerning EU APA principles are the principles of impartiality, consistency and legitimate expectations, transparency, fairness and the principle of efficiency and service (see Table 1). These principles are in current Slovene APA mostly defined only indirectly or partly through existing APA (and beyond) principles, but not as independent APA principles. Moreover, they can indirectly/abstractly derive as a required behaviour from certain APA rules. Croatia, on the other hand, lays more emphasis on the content of these core values through already existing fundamental APA principles. As regards the principle of privacy, Croatian APA has similar content as EU APA. Slovene APA, on the other hand, does not explicitly define it as a principle; however, the balance of privacy versus openness is recognized within APA rules. In our opinion, chiefly, the principles of fairness, transparency and efficiency and service are the ones that should be largely included in national APAs, with EU APA as a role model.

Tabel 1: Comparative analysis of the principles and rights in the EU APA v. Croatian and Slovene APs principles 


\begin{tabular}{|c|c|c|c|}
\hline $\begin{array}{l}\text { principles/rights } \\
\text { of } \\
\text { administrative } \\
\text { law and APs }\end{array}$ & & & \\
\hline No. & $\begin{array}{l}\text { EU APA } \\
\text { principles and } \\
\text { rules as } \\
\text { fundamental } \\
\text { rights }\end{array}$ & $\begin{array}{l}\text { Croatian } \\
\text { APs } \\
\text { principles } \\
\text { (APA and } \\
\text { beyond) }\end{array}$ & $\begin{array}{l}\text { Slovene } \\
\text { APs } \\
\text { principles } \\
\text { (APA and } \\
\text { beyond) }\end{array}$ \\
\hline 1 & Lawfulness & $\mathrm{XX}$ & $\mathrm{XX}$ \\
\hline 2 & $\begin{array}{l}\text { Non- } \\
\text { discrimination and } \\
\text { equal treatment }\end{array}$ & $\mathrm{XX}$ & $\mathrm{XX}$ \\
\hline 3 & Proportionality & $\mathrm{Xx}$ & $\begin{array}{l}\text { X (within } \\
\text { rights' } \\
\text { protection) }\end{array}$ \\
\hline 4 & Impartiality & $\mathrm{Xx}$ & $\begin{array}{l}\text { X (within } \\
\text { legality) }\end{array}$ \\
\hline 5 & $\begin{array}{l}\text { Consistency and } \\
\text { legitimate } \\
\text { expectations }\end{array}$ & $\mathrm{Xx}$ & $\begin{array}{l}\mathrm{X} \text { (within } \\
\text { rule of law } \\
\text { and } \\
\text { equality) }\end{array}$ \\
\hline 6 & $\begin{array}{l}\text { Respect for } \\
\text { privacy }\end{array}$ & $\mathrm{XX}$ & $\begin{array}{l}\text { Xx } \\
\text { (balancing } \\
\text { openness } \\
\text { and privacy) }\end{array}$ \\
\hline 7 & Fairness & $\mathrm{X}$ & $\mathrm{X}$ \\
\hline 8 & $\begin{array}{l}\text { Right to be } \\
\text { heard }\end{array}$ & $\mathrm{X}$ & $\begin{array}{l}\mathrm{Xx} \\
\text { (emphasized } \\
\text { within equal } \\
\text { rights) }\end{array}$ \\
\hline 9 & $\begin{array}{l}\text { Right to have } \\
\text { access to one's } \\
\text { file }\end{array}$ & $\mathrm{X}$ & $\begin{array}{l}\mathrm{Xx} \text { (as right } \\
\text { to be heard) }\end{array}$ \\
\hline 10 & $\begin{array}{l}\text { Duty to state } \\
\text { reasons }\end{array}$ & $\mathrm{X}$ & $\begin{array}{l}\mathrm{Xx} \\
\text { (emphasized } \\
\text { within legal } \\
\text { protection) }\end{array}$ \\
\hline 11 & $\begin{array}{l}\text { Notification of } \\
\text { administrative } \\
\text { decisions }\end{array}$ & $\mathrm{X}$ & $\mathrm{Xx}$ \\
\hline & $\begin{array}{l}\text { (Indication of) } \\
\text { Legal remedies } \\
\text { (within AP and }\end{array}$ & & \\
\hline
\end{tabular}




\begin{tabular}{|l|l|l|l|}
\hline 12 & $\begin{array}{l}\text { judicial } \\
\text { protection) } \\
\text { available }\end{array}$ & $\mathrm{XX}$ \\
\hline $\begin{array}{l}\text { Additional } \\
\text { modern } \\
\text { principles/rights } \\
\text { of } \\
\text { administrative } \\
\text { law and APs }\end{array}$ & $\begin{array}{l}\text { EU APA } \\
\text { principles and } \\
\text { rules as } \\
\text { fundamental } \\
\text { rights }\end{array}$ & $\begin{array}{l}\text { Croatian } \\
\text { APA }\end{array}$ & $\begin{array}{l}\text { Slovene } \\
\text { APA }\end{array}$ \\
\hline No. & $\begin{array}{l}\text { Transparency } \\
\text { Efficiency and } \\
\text { service }\end{array}$ & X & $\begin{array}{l}\text { Xx (indirect } \\
\text { only) }\end{array}$ \\
\hline 13 & Time limits & $\begin{array}{l}\text { XX (abstract } \\
\text { only) }\end{array}$ \\
\hline 15 & XX & Xx \\
\hline 14 & & & \\
\hline 13 & & & \\
\hline
\end{tabular}

As a result of EU membership, all Member States are required to follow common principles, inter alia to conduct efficient administrative procedures in accordance with the European administrative (procedural) law. In this context, we need to distinguish between (1) direct binding rules of the EU for Member States by sector-specific regulations, and (2) other acts, such as the EU Charter, with formal scope over the EU institutions only, but informally harmonizing national procedures as well. The very content/interpretation of the rules, however, differs from country to country. ${ }^{{ }^{6} \mathbf{6}}$ Table 1 indicates that in terms of continuity of the administrative system, the over 50-year-old Slovene administrative tradition is indeed appropriate, particularly as regards traditional principles. On the other hand, the comparison with the revised APA in Croatia ${ }^{\mathbf{3 7}}$ shows that this can also imply a certain degree of rigidity and the preservation of conditions that no longer match the societal needs of modern times. Croatia, for instance, introduced several new APA principles in 2009, such as broadened rights to legal remedy, proportionality and data access versus protection. On the other hand, some rights - such as the right to be heard are reduced from previous principles to rules. The highlighted image of principles that in a given country are more intensely expressed (XX or Xx v. $\mathrm{X}$ ) thus shows an evident difference in codification already in countries as related as Slovenia and Croatia. In addition, given the rather vast case law of the ECtHR, ${ }^{38}$ both countries need additional improvements to fully enact and implement such principles at the EU level.

In the light of these findings, the article analyses the regulation of the Slovene and Croatian APA, focusing on an element of good administration that is, in our assessment, crucial for this particular area and time, i.e. the reasonable time limits for decision-making. The EU Charter and ECHR, in 
fact, provide that everyone is entitled to good administration, including legally (judicially) ${ }^{\mathbf{3 9}}$ protected decisions within a reasonable time. Nevertheless, data of the ECtHR show an increasing number of cases (namely, a third of all cases) directly related to the breach of these principles/rights. ${ }^{40}$

\section{Normative analysis of APA in Slovenia and Croatia in the light of an efficient and user-oriented administrative decision-making in the $\mathrm{EU}$}

\section{II.I. Analysis of accelerative, braking and user-oriented institutions in Slovene and Croatian APA}

The procedure is deemed efficient when it is conducted rapidly yet generates correct and legitimate decisions. The efficiency in administrative relations is legitimate only if it coincides with fairness and legality, meaning that the contrast between economy and (formal) legality (due process) might just be an artificial dilemma. ${ }^{\mathbf{4 1}}$ The following is a normative analysis of APA in terms of selected institutions believed to have accelerative (and/or) user-oriented or braking effects. As seen in Table 2, the existing Slovene and Croatian legislation contains a number of accelerative elements. These are selected cases; hence, the list below should not be taken to be exhaustive. Among the existing accelerative elements, the following are worth applying also in the future: legal assistance, combining related matters into a single procedure, oral decisions, the possibility of issuing a partial decision whereby the agency at least partly avoids delay, ${ }^{\mathbf{4 2}}$ flexible rules regarding the presentation of evidence (when possible), settlement, summary declaratory proceeding, preventive encouragement of the parties to participate with the possibility of sanctions, etc.

Tabel 2: Selected examples of accelerative and braking institutions under the Slovene and Croatian APA

\section{Accelerative institutions under the Slovene and Croatian APA}

Jurisdiction: transfer of jurisdiction in case of excessive decisionmaking times

Parties and their representatives: temporary representative, (joint) authorized person

Communication between agencies and parties: sanctions for participants if they unjustifiably fail to respond to the invitation; less formalization in summary proceedings; e-applications, enotifications and e-serving, single entry point; fiction of servicing

Restitutio in integrum (RII)

From the beginning of procedure to the issuing of decision: test of procedural prerequisites; merging of matters; start of procedure with edict; (fictional) withdrawal of claim; settlement between parties; summary declaratory proceeding without hearing and act based on probability; preclusions; shared burden of proof; video 
hearings

Presentation of evidence: legal presumptions need not to be proved; statement by the party as evidence; expert witnesses; presumed issuance of consent/opinion by another agency

Decision: act not interfering with public interest only in form of written note; oral, temporary, partial, supplementary acts; time limits and fictions

Legal remedies: time limit; the appellate agency may renew the procedure or resolve the matter; replacement decision and corrections by the inferior agency; examination of reasons for selected extraordinary legal remedies in the course of appellate procedure; waiver of appeal

\section{Selected examples of APAs institutions with a (possibly) braking character}

Unclear mutatis mutandis application of APA in other public law matters

Too broad access of (accessory) participants

Instructional time limits to issue a decision; (negative) fictions; limited decision-making on second instance in the event of delays at inferior agencies

Possible extension or submitting other claim/modification of a claim

Suspension of procedure due to preliminary question

Restriction to summary declaratory proceedings only if the claim is granted or for urgent measures in public interest

Appeal as a principle and its suspensiveness, cassation, appeal as procedural presumption for judicial contest; prohibition of transfer of jurisdiction; extent/number of extraordinary legal remedies (also ex officio)

These institutions indeed prove that the legislature is aware of the value of a rapid conduct of procedures, which it attempts to stimulate by means of various procedural solutions. Quantity, however, is no guarantee of efficiency of administrative decision-making as a whole and might, to a certain extent, even result in excessive formality. Given the results of the analysis, the present regulation can be criticized mainly for its fragmentation and shortcomings in terms of the procedure as a whole. ${ }^{43} \mathrm{In}$ fact, despite the previous partially successful accelerative solutions, a single ineffective institution or its insufficient implementation can undermine the efficiency of administrative decision-making as a whole.

Moreover, there are several institutions that not only have accelerative effects but are also user-oriented and, as such, are a demonstration of good administration. A procedure that is user-friendly and perceived as efficient can, however, at the same time imply a greater burden for the relevant agency. Nevertheless, in accordance with the principles of lawfulness and protection of the rights of the parties, such rights must be guaranteed in the 
course of procedure. For instance, in Slovenia the abolition of territorial jurisdiction can indeed contribute to relieving specific agencies, but, on the other hand, it can result in an increased number of claims in the territory of the agencies having jurisdiction over the capital or other major city. This measure is thus perceived to contribute, above all, to greater user satisfaction, yet only provided that in the territory where they file their application the decision is issued in due time. If this means that the administrative units covering the territory of major municipalities have greater workload and therefore take longer to issue the relevant decisions, the procedures are, of course, less favourable to both the parties and the agency. For this reason, it is necessary to be up to date with the situation and timely direct the party to another suitable location where the service will be provided within reasonable time. Other institutions relevant to the party include the basic principles of protection of the rights of the parties, the right to be heard and the right of appeal, which are the fundamental values that guide the officials throughout the procedure. The said principles are also reflected in other institutions (see Table 2), such as the possibility to participate in the procedure through a representative, e-applications, the right to participate in the procedure, give comments, have access to file, the right to legal remedies, etc. 44 It needs to be underlined, however, that the above elements are not always user-oriented since the primary goal of administrative procedure - in addition to implementing the rights of the parties - is to protect the public interest. Namely, obligation of timely decision-making is part of procedural fairness $\mathbf{4 5}$ and derives from fundamental principles of legality, protection of parties' rights and public interest as well as the principle of economy. However, we must not forget that, as argued above, public authority is primarily obliged to protect the public interest. Therefore, APA regulation itself should ensure a balance between procedural guarantees and efficiency. ${ }^{46}$ This means timeliness of procedure should never be to the detriment of the procedure's legality and establishment of the facts of the dispute.

On the other hand, there are several institutions in APAs believed to have a braking effect (second part of Table 2). ${ }^{47}$ Critical issues include the unclear application of APA in other public law matters, which might lead either to non-utilization and thus insufficient guarantee of the minimum procedural standards or to misinterpretation as to how and when APA is to be used in such matters. Other pressing problems prolonging the duration of procedures are the incompleteness of applications and the time limits for decisions that start to apply the moment the application is completed, even if the procedure could have been going on for several months already with (late) calls for supplementing the application, without legal remedies being available to the party (appeal on grounds of administrative silence is in fact permitted only when silence arises, i.e. after the expiry of the time limit for decision) and the possibility to transfer the matter between inferior and superior agencies in the appellate procedure. As regards the duration of procedures, the existing regulation allows a (too) strong influence of (accessory) participants, which have many possibilities to enter the procedure (legal interest based on sector-specific laws that do not make it clear which persons are entitled to participate) as well as the power to suspend the procedure by means of suspensive appeal. 


\section{II.II. Slovene APA in the context of modern Croatian approaches}

In order to make a list of the changes proposed for the future (see Section C), a comparative analysis of the Croatian and Slovene regulation of the duration of APs is provided (Table 3). Despite the Croatian APA being adopted relatively late, i.e. ten years after the Slovene version, it is (again) clear that the Croatian legislature opted for a more modern approach. Also worth noting is that two further years had passed before Croatia adopted a new Administrative Dispute Act (ADA). ${ }^{48}$ Thus, APs last longer both because the said Act came into force later and because it introduced twoinstance decision-making besides the two instances provided by the APA. However, ADA was amended in 2014 to make more effective judicial protection of citizens' rights within administrative justice.

Tabel 3: Comparative analysis of duration of procedures under Croatian and Slovene APAs

\begin{tabular}{|l|l|}
\hline $\begin{array}{l}\text { Selected accelerative/user- } \\
\text { oriented elements in the } \\
\text { Croatian APA }\end{array}$ & $\begin{array}{l}\text { Slovene APA comparison - } \\
\text { YES / NO }\end{array}$ \\
\hline $\begin{array}{l}\text { In addition to individual } \\
\text { administrative acts, also applicable } \\
\text { to administrative contracts and } \\
\text { non-authoritative administrative } \\
\text { actions with direct impact on legal } \\
\text { interests of parties and public } \\
\text { services implementation }\end{array}$ & $\begin{array}{l}\text { Partly yes: individual } \\
\text { administrative acts; other } \\
\text { public law matters; providers } \\
\text { of public services when } \\
\text { deciding on parties' } \\
\text { rights/obligations, no option } \\
\text { of administrative contracts in } \\
\text { APA }\end{array}$ \\
\hline $\begin{array}{l}\text { Principles: proportionality in } \\
\text { protection of parties' rights and } \\
\text { public interest; efficiency and } \\
\text { economy; access to information; } \\
\text { protection of acquired rights }\end{array}$ & $\begin{array}{l}\text { Partly under protection of } \\
\text { parties' rights and public } \\
\text { interest; no explicit emphasis } \\
\text { on efficiency and simplicity; } \\
\text { information partly under APA }\end{array}$ \\
\hline Single entry point & Yes \\
\hline E-communication & Yes \\
\hline $\begin{array}{l}\text { Summary declaratory proceedings } \\
\text { as a rule }\end{array}$ & No (exceptionally) \\
\hline Time limits for decisions set in days & $\begin{array}{l}\text { In months, although app. } \\
\text { same time }\end{array}$ \\
\hline $\begin{array}{l}\text { Administrative silence }- \text { neutral, } \\
\text { possible positive fiction if provided } \\
\text { by sector-specific law }\end{array}$ & $\begin{array}{l}\text { Negative fiction; positive } \\
\text { fiction: not in APA (except for } \\
\text { approvals of other } \\
\text { administrative bodies in } \\
\text { composite procedures); there } \\
\text { is positive fiction in several } \\
\text { sector-specific laws }\end{array}$ \\
\hline
\end{tabular}


Only 3 extraordinary legal remedies, special legal remedy objection in procedures dealing with administrative contracts and public services
5 extraordinary legal remedies, objection restricted and abstractly in relation to public services by mutatis mutandis application of APA

With 171 articles, compared with 325 in the Slovene APA ${ }^{49}$, the new Croatian APA is indeed less comprehensive but features modern approaches that are highly relevant for Slovenia as well. One of them is the scope of application - in addition to individual administrative acts, the Croatian APA also applies to administrative contracts and non-authoritative administrative actions with direct impact on the rights/obligations/legal interests of the parties and public services implementation. ${ }^{\mathbf{0}}$ Examples of good practice also include the recognition of the importance of efficient administrative decision-making based on fundamental principles, summary declaratory proceedings as a rule, positive fiction anticipated already under APA, and restriction of legal remedies. Its shortcomings compared with the Slovene APA are the following: "unelaborated" notion of subsidiary application of APA, the professional requirements of officials are not clearly defined, the single entry point is not fully functioning, time limits for decisions are only determined for procedures initiated at the request of the party, ${ }^{\mathbf{5 1}}$ references to other laws, e.g. in relation to evidence proceeding or judicial execution of financial obligations..$^{\mathbf{2}}$

As stressed by several authors, ${ }^{\mathbf{5 3}}$ any change does not necessarily mean modernization. Modernization is in fact a type of administrative change and means pursuing new concepts as regards the administration's role in the society and the technical upgrading of administrative activity. For the countries that lack tradition and established social relations, moderate or gradual changes are a much safer option than the radical processes of deregulation, privatization and simplification.

\section{From results of the analysis to changes of APA principles and rules}

On the basis of normative and comparative analysis performed of selected APA, it may be concluded that the Slovene and Croatian regulations both show the influence of and the affiliation with the German tradition (with Austrian influence), reflected in a formal approach that corresponds to Weber's hierarchically regulated administration. Moreover, current AP regulations sometimes reflect judicial procedures. ${ }^{54}$ Despite some modern approaches (e.g. e-communication), both countries still preserve an (over)detailed regulation of APA. Hence we suggest, in what follows, specific changes to APA, which we believe to contribute to faster procedures and greater user-orientation also in the light of the standards of good administration. In doing so, we rely on the understanding that reasonable timing in administrative and administrative-judicial procedures - as elements of good administration and due process - developed through time as fundamental human right(s). 55

As regards the issue of unclear application of APA in other public law matters, we suggest that, first, a set of procedural principles and rules 
applicable in such matters be defined. By specifying the matters subject to APA and the scope of its application, we can contribute to legal certainty and efficiency of decision-making. We also propose the introduction of new fundamental principles or the supplementation/restructuring of existing principles, particularly in accordance with the EU Code and the (draft) EU APA and CM/Rec(2007)7 on good administration. This implies the introduction of principles such as the following (see also Table 4). ${ }^{\mathbf{5}}$ First, equality and impartiality in such regard that similar cases should be dealt with in the same manner and different cases in a different manner. ${ }^{57}$ Second, the significance of participation, supplementing the right to be heard with the right of access to one's file, cannot be underestimated..$^{\mathbf{8}}$ Among contemporary principles that are most emphasized, there are also transparency and restriction of access or privacy as an exception rather than as a rule. 59 Furthermore, we find the important principle of economy with the explicit provision that actions must be carried out and decisions taken within a reasonable time. However, as an umbrella principle, there should be a notion of public service being available, easy, giving assistance and being smooth, and oriented towards solving real-life problems, etc. - all resulting in a cultural shift in PA to its »service-mindedness «. ${ }^{\mathbf{6 0}}$ Regarding the latter, it is especially important for Slovenia and Croatia as other Eastern European countries to bridge former understanding of an authority within a (post)socialist system. An authority has been seen in this context as a superior, and a party as a subordinate one since administrative proceedings have been regulated, mainly reflecting so-called (communist) "capture of the state" and a rather legalistic approach versus citizens. These characteristics have led to implementation gaps in the region even regarding traditional principles of lawfulness and proportionality. On the other hand, contemporary good administration requires administrative procedures as a dialogue tool between an authority and citizens as equal partners in order to respond efficiently to fundamental social and economic changes that have occurred during the last few decades. The notion of service-mindedness by a participative PA is hence pursued also on a systemic level, for instance by national strategies on PA development, adopted in Slovenia and Croatia in 2015. ${ }^{\mathbf{6 1}}$ However, this orientation needs to be supported by more tangible rules as "only" principles stipulated by the APA and sector-specific laws. In this sense, some simplifying measures have already been put in place in Slovenia and Croatia lately, particularly for business entities, such as joined-up procedures, shortened deadlines, positive fictions in administrative silence, less formalised applications, IT systems for submitting applications and notification, or exchange of information as PA burden instead of parties. Nevertheless, there is (1) room for further participative institutes, e.g. alternative dispute resolution and administrative contracts, and (2) besides regulative amendments, systemic organizational changes and training of officials are necessary to develop new attitudes to parties, timeliness included.

There is no doubt, however, that APA should be redefined together with other systemic laws. A national constitution and umbrella laws need to codify fundamental principles with APA in a coordinated way; otherwise they remain unimplemented or even counter-productive. Above all, these are the laws concerning public administration, civil servants, freedom of 
information, judicial review in administrative matters, etc. We believe that the main principles of APA should consequently be regulated by certain respective laws, on a constitutional basis. Certain principles to be followed by the APA need to be in compliance, especially with those laws as indicated in Table 4.

Tabel 4: Selected fundamental principles as codified by systemic legislation on good administration

\begin{tabular}{|c|c|c|c|c|c|}
\hline $\begin{array}{l}\text { Fundamental } \\
\text { Principles } \\
\text { codified by } \\
\text { APA }\end{array}$ & $\begin{array}{l}\text { PA } \\
\text { Act }\end{array}$ & $\begin{array}{l}\text { Civil } \\
\text { Servants } \\
\text { Act }\end{array}$ & $\begin{array}{l}\text { Freedom of } \\
\text { Information } \\
\text { Act }\end{array}$ & $\begin{array}{l}\text { Administra- } \\
\text { tive Dispute } \\
\text { Act }\end{array}$ & Constitution \\
\hline $\begin{array}{l}\text { Lawfulness, } \\
\text { impartiality } \\
\text { and equality } \\
\text { with embedded } \\
\text { proportionality } \\
\text { on public } \\
\text { interest v. } \\
\text { private rights }\end{array}$ & $\rightarrow$ & $\rightarrow$ & & $\rightarrow$ & $\leftarrow$ \\
\hline $\begin{array}{l}\text { Participation } \\
\text { and right of } \\
\text { parties to be } \\
\text { heard }\end{array}$ & $\rightarrow$ & & & $\rightarrow$ & $\leftarrow$ \\
\hline $\begin{array}{l}\text { Transparency, } \\
\text { right to access } \\
\text { to information } \\
\text { and privacy } \\
\text { protection }\end{array}$ & $\rightarrow$ & & $\rightarrow$ & & $\leftarrow$ \\
\hline $\begin{array}{l}\text { Time limits as } \\
\text { part of fair trial } \\
\text { and efficient } \\
\text { service }\end{array}$ & $\rightarrow$ & & & $\rightarrow$ & $\leftarrow$ \\
\hline $\begin{array}{l}\text { Effective legal } \\
\text { remedies and } \\
\text { judicial } \\
\text { protection } \\
\text { against PA }\end{array}$ & $\rightarrow$ & & $\rightarrow$ & $\rightarrow$ & $\leftarrow$ \\
\hline
\end{tabular}

Presently, some of these principles have already been stipulated by constitutions and respective laws in Slovenia and Croatia (see Table 1), but not consistently and not rarely »hidden « among other guarantees, such as timeliness (only) as a part of access to the court in Art. 23 of the Slovene Constitution. Consequently, officials in PA face specific ethical and legal dilemmas, which arise from their relation towards other persons or institutions involved in public governance. ${ }^{\mathbf{6 2}}$ We propose further and autonomous development of these principles. 
In terms of introducing new principles in already established practice, the important role also goes to the case law. The latter is in both common and civil law, a system that not only uses law, but also creates it. However, in common law, case law establishes precedents, unlike civil law, where its main function is to judge in concrete cases, based on relevant legislation. ${ }^{63}$ By resolving real-life situations, case law detects real-life problems and is a way to establish value-based criteria, i.e. principles, even before they are enacted. The legislature will, on the basis of such recognized jurisprudence and possible "public discourse" followed by actual relevant policies in time and space, decide which of these principles need to be codified. Namely, codification aims as legal ground and recognition, ensuring legal protection. However, if the actual purpose and values of certain principles cannot be achieved, e.g. it is too ideal, there is no point in its codification. That means the legislator should enact principles in accordance with the actual need of society in certain time and space.

Furthermore, we must specifically not underestimate excessive delays considered »by far the most common issue raised before ECtHR « and constituting »grave danger «, in particular for the rule of law and access to justice. ${ }^{64}$ To achieve efficiency, it is therefore crucial to enact specific rules as well as to combine various activities, legal and organizational (Figure 1). Legal measures (under APA and other regulations) are those that (a) stimulate faster decision-making and prevent excessive delays (e.g. following the model of ECtHR, restrict the extent of the application or the model procedure, and above all merit, i.e. reformation decision-making in appeal and judicial procedures instead of cassation mandates only), and (b) in case of violations provide the parties with efficient legal protection (under APA and/or national compensation). Further organizational measures should be given priority over legal measures as delays are often a result of non-optimum manner of work in PA and lack of human resources. Moreover, hybrid, i.e. legal-organizational measures, e.g. mediation, see CoE Rec(2001)9 on ADR in administrative matters, or informatization of APs and PA conduct ${ }^{\mathbf{6 5}}$ are to be introduced and implemented.

\section{Measures to step up administrative decision-making and achieve good administration}

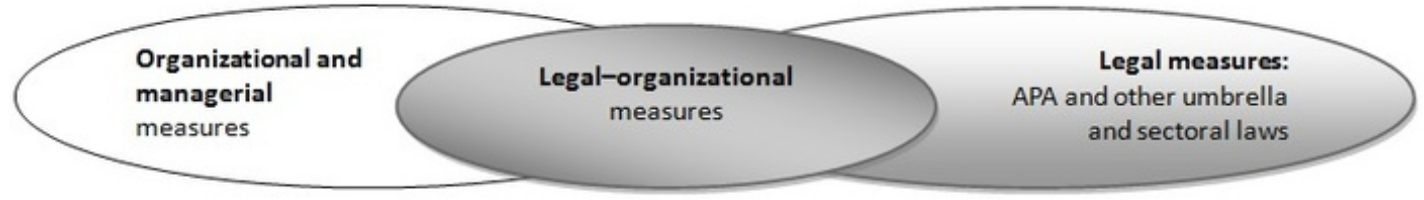

Specifically for APA, we recommend several interconnected measures, some of regulatory and other of implementation nature for Slovene and Croatian policymakers and their PAs. ${ }^{\mathbf{6 6}}$ We believe the most important are mixed measures aiming at proceedings that are more effective. For instance, on the agencies side the assumption of authority by appellate or supervisory bodies if (systemic) delays are detected at a certain agency should be enhanced. At the same time, law might at least by enumerative criteria restrict the influence of accessory participants on the course of procedures to matters where the decision has utmost importance or serious consequences for them. Rather executive but efficient are e-supported 
steps, where present APAs allow e-applications and e-servicing, but the level of implementation is low, so some marketing could be introduced (such as abolishment of administrative fees when parties participate in ecommunication).

With regard to timing, we recommend to the legislatures in both countries to set the time limit for the adjournment of procedure in cases under Article 153 of the Slovene APA as of the moment the relevant circumstances arise (ex lege), and fix a final time limit for continuation (e.g. 2 months in Slovenia or 30 days in Croatia). If the procedure does not continue by the said time limit, the party should be given the possibility to appeal on grounds of administrative silence. As regards the issue of incomplete applications and the start of the time limit for decision, such time limit should begin on the day the application is received (although incomplete), while the general time limit for issuing a decision should be extended (e.g. 3 months). Additionally, at least a normative educative clause to promote alternative or consensual dispute resolution should be introduced, both prior to decision and in procedures involving legal remedies. In general, on the one hand, legal remedies should be restricted to provide greater legal certainty, while, on the other, the scope of APA should be increased in terms of, for example, administrative contracts and real or general administrative acts.

It is also particularly important that APA follows the established concept and specifies the basic institutions, instead of having a general administrative procedure law that refers to the (mutatis mutandis or subsidiary) application of, for example, the law that regulates adjudication proceedings, ${ }^{67}$ as the objectives and principles of APs are quite different. Put differently, rules of adjudication do not support public interest satisfactorily but only by constitutional guarantees for parties. Consequently, if APA refers to adjudication proceedings, substantive administrative and procedural legislation can counter each other.

\section{Conclusions}

In nearly every country of the world, administrative procedure is one of the most important decision-making tools in public law relations and PA conduct. Following recent theories and regulatory shifts at the national and supranational (in particular, EU) levels, AP can be designed as a communication channel of policy cycle among key stakeholders in contemporary society within the good governance and good administration doctrines. In consequence, AP development is facing a global convergence in major trends and goals. The same goes for certain institutions in the general law (usually APA). However, such major shifts take time, and a step-by-step approach is recommended to avoid being faced later with the problem of pure window dressing reforms resulting from persisting old administrative cultures. Inevitably, one also needs to take into account that about all changes of traditional APs are mainly legally determined but cannot be only regulatorily driven.

Nevertheless, as set in legal theory, EU and Member States' legislation and EU and ECtHR case law, APs' efficiency is defined, in particular, by speedy or timely conduct and effective coordination of legal interests protected in the procedure (public v. one or more private interests), including effective 
legal remedies. On the basis of a study and comparative analysis of Slovene, Croatian and draft EU APAs, we can conclude that the codification of APs is a tool in the hands of the State to modernize administrative decisionmaking in the sense of good administration. Administrative decisionmaking should be user-oriented both in the sense of efficiency of procedures and in terms of lawfulness, while preserving the primary goal, which is to protect the public interest, and restricting regulation only to areas where such protection requires it.

Despite the common endeavour for removal of administrative barriers, fundamental, classic and modern administrative law principles have to be ensured in APs, as being particularly characteristic of the German-oriented legal systems and effective and equivalent EU law. In this respect, the comparative analysis performed leads to several conclusions. Slovene and Croatian overall (systemic) regulation complies with EU principles that derive from Recommendation 3. However, national APAs do have certain differences in that they emphasize certain aspects in more detail. Namely, we have to bear in mind national APAs are not only recommendation as EU APA, but law, applied in real-life cases. It gives us an overall picture on the relevance of values and state of society and, consequently, PA evolution at the national level. Slovene regulation has been following Germanic tradition and previous Yugoslavian law with the same set of principles for more than 50 years. That is not bad, although there is a lack of more flexible and citizen-oriented principles, such as service mindedness. Croatia, on the other hand, is somewhere in between tradition and modernization. Basic principles promoted by EU APA, which are essential for the rule of law, such as lawfulness, non-discrimination and equal treatment, derive from national constitutions in both countries. Furthermore, both national APAs promote lawfulness as the first fundamental principle, which is in accordance with separation of powers and strict bond of public authorities to the law. Proportionality also derives from national constitutions, and is promoted by APAs, in Slovenia as part of fundamental principles, i.e. protection of parties' rights and public benefit (Article 7), and in Croatia as the principle of proportionality in protection of parties' rights and the public interest. Both national APAs should reconsider including principles in addition to the existing fundamental principles, turning PA into a more service-minded culture. That is especially the case for Slovenia, which is still based on the Germanic approach. As such, we expose from EU APA particularly the principles of impartiality, consistency and legitimate expectations, transparency, fairness and the principle of efficiency and service.

On the other hand, national APAs include the principles of right to be heard, legal remedies and help to a party, which are not explicitly defined as principles in EU APA, but only derived from rules in Recommendation 4. We can conclude that national APAs recognize these as core values, important for APs and therefore fundamental criteria, used to interpret other APA rules; however, at the EU level they are recognized as a duty how to behave.

The main differences between the Slovene and Croatian APA are as follows: Croatian APA lays more emphasis on service-mindedness promoting the independent principle of help to a party (in Slovenia as part of the principle of protection of parties' rights and public benefit), principle of data access 
and respect for privacy and protecting rights attained by the parties. Moreover, the Croatian legislature defined summary proceedings as a rule (in Slovenia it is the opposite), positive fiction already under APA, limitation of possible legal remedies, inclusion of public contracts and obligation to use APA also when conducting public services. In our analysis, we found these institutions to be good examples, which could also be followed by the Slovene legislature when enacting new APA.

By identifying accelerative and braking mechanisms in individual regulations and sharing good practices, the overall efficiency of decisionmaking can be enhanced. Namely, as regards decision-making in reasonable time, both national APAs do include fundamental principles, i.e. the principles of effectiveness and (or) economy, which are important values to be followed in every PA conduct, not just final administrative decision-making, but also when performing judicial review. Croatian APA lays even more emphasis on it through the principle of legal remedy, which requires deciding within a prescribed time limit. EU APA, on the other hand, defines decision-making in reasonable time only as a rule and focuses on issuance of administrative acts, setting a general time limit of 3 months. We do find it important that this right is recognized by APA at the level of principle as a value to be promoted throughout the procedure as a whole (including judicial review). However, national regulation should consider redefining the general time limit to issue administrative decisions in accordance with EU rule, i.e. 3 months, calculating from the day a party submitted an application, even if incomplete. Based on EU procedural rules as defined by ReNEUAL, Slovenia and Croatia should, in further AP enactments, follow the holistic regulation approach, i.e. including individual, real and general administrative acts, possibility of alternative dispute resolutions, public contracts and information management in one single act. This would improve not only efficiency but also legal certainty for all involved participants. Finally, when redefining APA, other systemic laws should be taken into consideration, especially consistency, as well as differentiation with judicial protection regulation. One possibility would be to regulate the all-administrative procedural field in AdministrativeProcedural Code, which would also include judicial procedure.

\section{Noten}

1 Jacques Ziller, Administrative simplification through a general law on administrative procedures for the protection of citizens' rights and economic development: the key issue of legal certainty and predictability in administrative performance, Sigma, 1, 6-7 (Ankara, 8-9 May 2008), http://www.sigmaweb.org/publicationsdocuments/41326672.pdf,; cf. John S. Bell, Comparative Administrative Law, in Handbook of Comparative Law, 1259, 1278 (Mathias Reimann \& Reinhard Zimmermann eds., 2006); Wolfgang Rusch, Citizens first, Good administration through general administrative procedures in, Modernising Administrative Procedures, Meeting EU Standards, Regional School of Public Administration, 3-14 (2011).

2 More in Jürgen Schwarze, European Administrative Law in the Light of the Treaty of Lisbon: Introductory remarks, Workshop on EU 
Administrative Law: State of Play And Future Prospects, 7-27 (León-Spain, Briefing Notes 2011); Jacques Ziller, The Continental System of

Administrative Legality, in Handbook of Public Administration, 167 (B. Guy Peters \& Jon Pierre eds., 2009); Principles of Good Administration in the Member States of the European Union, Statskontoret, 1, 33, 74-76 (2005), http://www.statskontoret.se/upload/Publikationer/2005/200504.pdf.

3 Cf. Tina Sever, Iztok Rakar, Polonca Kovač, Protecting Human Rights Through Fundamental Principles of Administrative Procedures in Eastern Europe, 5 (4) DANUBE: Law And Economics Review, 249-275 (2014).

4 Code des relations entre public et l'administration (accepted in October 2015) - entered into force on 1 January 2016.

5 Herwig C. H. Hofmann, Jens-Peter Schneider, Jacques Ziller (eds.), The ReNEUAL Model Rules, ReNEUAL (2014), available at: http://www.reneual.eu/.

6 See Jacques Ziller, Alternatives in Drafting Administrative Procedure Law, European Parliament, DG For Internal Policies Policy department C, Citizen's Rights And Constitutional Affairs (2011), http://www.europarl.europa.eu/RegData/etudes/note/join/2011/462417/IPOLJURI_NT(2011)462417_EN.pdf, 13-14; and Resolution of 15 January 2013 with recommendations to the Commission on a Law of Administrative Procedure of the European Union (2012/2024(INI)), European Parliament (2013), http://www.europarl.europa.eu/sides/getDoc.do? type $=$ TA\&reference $=$ P7-TA-2013-0004\&language $=E N$.

7 Europeanization of administrative law; Schwarze, supra, note 4, at 11-12.

8 Gorazd Trpin, Temeljna načela postopka za varstvo in uveljavljanje pravic posameznikov $v$ razmerju do upravnih in samoupravnih organizacij [Fundamental Principles of Procedure for Protection and Implementation of individual's rights in relation to administrative and selfregulatory organisations], 43 Zbornik Znanstvenih Razprav, 151 (1983).

9 Humberto Ávila, Theory of Legal Principles, 34-35, 40-41 (2007). More on principles see also Jan H. Jans, Sacha Prechal, R.J.G.M. Widdershoven (eds.), Europeanisation of Public Law, 137-142 (2015).

10 Marijan Pavčnik, Teorïa Prava [Theory of Law], 81-82 (1999).

11 On codification of principles, see Francisco Cardona, Checklist for general law on administrative procedures, SIGMA, 2005, http://www.sigmaweb.org/publicationsdocuments/37890936.pdf. On AP codification see Rusch, supra, note 3, at 11-12; Jean-Bernard Auby, Codification of Administrative Procedure, 4, 28 (2014).

12 Cf. Cardona, id., at 1-3. Cf. also Diana-Urania Galetta, Herwig C. H. Hofmann, Oriol Mir Puigpelat and Jacques Ziller, The General Principles of 
EU Administrative Procedural Law, 11-14 (2015).

13 Javier Barnes, Towards a third generation of administrative procedure, in Comparative Administrative Law, 336, 337-339 (Susan Rose-Ackerman \& Peter L. Lindseth, eds, 2011); Polonca Kovač, Regulacija in izvajanje upravnih postopkov - uvodna študija [Regulation and conduct of administrative procedures - introductory study], in Upravno-procesne Dileme o Rabi Zup, 2 [Administrative-procedural Dilemmas in The Use of APA, 2], 25, 32 (Polonca Kovač ed., 2012).

\section{Id., 350-354.}

15 Kovač, supra, note 15, at 27-31. $C f$. Sever, Rakar, Kovač, supra, note 5: analysis of NPM $v$. governance/administration driven APAs' principles.

16 See analysis by Rhita Bousta, Who Said There is a "Right to Good Administration"? A Critical Analysis of Article 41 of Charter of Fundamental Rights of the European Union, 19(3) European Public Law, 481-488 (2013).

17 Cf. for instance European Court of Justice Case Kühne and Heintz C453/oo $v$. Productschap voor Pluimvee en Eieren (Jan. 13, 2004) on autonomy of national procedural law in states. Available at: http://eurlex.europa.eu/.

$18 C f$. Ziller, supra, note 8; Hofmann, Schneider, Ziller, supra, note 7.

19 Cf. Herwig C. H. Hofmann \& Bucura C. Mihaescu, The Relation between the Charter's Fundamental Rights and the Unwritten General Principles of EU Law: Good Administration as the Test Case, 9 European Constitutional Law Review, 96-99 (2013).

20 Cf. Auby, supra, note 13, at 27.

21 Cases T-193/o4 Tillak $v$. Commission of the European Communities (Oct. 4, 2006), and C-604/12, H. N. v. Minister for Justice, Equality and Law Reform and Others of Ireland (May 8, 2014). On Tillak case and many others regarding individual elements of good administration, see Bousta, supra, note 18 , at 482,484 . See case law related to principles in administrative law in Galetta, Hofmann, Puigpelat, Ziller, supra, note 14, at 8 et seq.

22 For details see Hofmann \& Mihaescu, supra note 21, at 73-101: on its material, personal and institutional scope.

23 For a detailed analysis see Itai Rabinovici, The Right to Be Heard in the Charter of Fundamental Rights of the European Union, 18 (1) European Public Law, 149-173 (2012).

24 EU Code, issued in 2001 and complemented in 2012, available at: http://www.ombudsman.europa.eu/en/resources/code.faces\#/page/1; $c f$. 
Marta Hirsch-Ziemebińska, The application of the European Code of Good Administrative Behaviour by the European Institutions, in Pursuit of Good Administration, 1, 10 (Warsaw, 29-30 November 2007), http://www.coe.int/t/dghl/standardsetting/cdcj/administrative\%2olaw/conferences/DAba-Conf\%20_2007_\%209\%20e\%20-\%20M.\%20Hirsch-Ziembinska.pdf.

25 More in Council of Europe (CoE, 2015), available at: http://www.coe.int/.

26 Kudta v. Poland, ECHR App. No. 30210/96 (Oct. 26, 2000), http://hudoc.echr.coe.int/.

27 Lukenda v. Slovenia, ECHR App. No. 23032/02 (Oct. 6, 2005); Mandić \& Jović v. Slovenia, ECHR App. No. 5774/10, 5985/10 (Oct. 20, 2011), both available at: http://hudoc.echr.coe.int/.

28 Počuča v. Croatia, ECHR App. No. 38550/02 (Jun. 29, 2006); Božić v. Croatia, ECHR App. No. 22457/O2 (Jun. 29, 2006); Śtokalo \& others $v$. Croatia, ECHR App. No. 15233/05 (Oct. 16, 2008), all available at http://hudoc.echr.coe.int/.

$29 C f$. Rusch, supra, note 3, at 13.

3o Sever, Rakar, Kovač, supra, note 5, at 259, 270; particularly the laws on state or public administration and on civil servants.

31 Cf. Sever, Rakar, Kovač, supra, note 5, at 269-270.

$32 C f$. Ivan Koprić, Novi zakon o općem upravnom postopku - tradicija ili modernizacija [New APA - tradition or modernization], in Modernizacija Općeg Upravnog Postupka i Javne Uprave u Hrvatskoj [Modernization of General Administrative Procedure and Public Administration in Croatia], 21, 31-32 (Ivan Koprić \& Vedran Đulabić eds., 2009).

33 See Statskontoret, supra, note 4, at 73; and Ziller, supra, note 4, at 168.

34 Koprić, supra, note 34.

35 For details see Hofmann, Schneider, Ziller, supra, note 7.

36 Statskontoret, supra, note 4, at 72-76.

37 Same in Koprić, supra, note 34; Rusch, supra, note 3; Sever, Rakar, Kovač, supra, note 5.

38 See Document "Violations by Article and by State (1959-2015)" by European Court of Human Rights, available at http://www.echr.coe.int/Documents/Stats_violation_1959_2015_ENG.pdf.

39 More in Jonathan Auburn, Jonathan Moffett, Andrew Sharland, Judicial Review: Principles and Procedure, 81-105 (2013). 
40 CoE, 2015, supra, note 27.

41 Kovač, supra, note 15, at 39. Or by Statskontoret, supra, note 4, at 78: It is necessary to pursue the balance and simultaneous duality of guarantees, both of public interest, i.e. enforcement of public policies of the regulators, and the rights and legal interests of the parties and persons concerned, i.e. the regulated subjects.

42 Tone Jerovšek \& Gorazd Trpin (eds.), Zakon o splošnem upravnem postopku s komentarjem [APA with commentary], 611 (2004).

43 Kovač supra, note 15 , at 57-61.

44 Koprić, supra, note 34; Rusch, supra, note 3.

45 Polonca Kovač, Šutnja uprave između teorije i prakse u Sloveniji [Administrative silence between theory and practice in Slovenia], 2 Zbornik Pravnog Fakulteta Rijeka, 869-901 (2011).

46 Cardona, supra, note 13 , at 2.

47 Jerovšek \& Trpin, supra, note 44; Kovač supra, note 15; Polonca Kovač \& Matjaž Remic, Izbrani vidiki razvoja APA - prek današnjih problemov $k$ jutrišnjim ciljem [Selected aspects of APA development - from present problems to future solutions], 33 Pravna praksa, 21-23 (2014).

48 Koprić, supra, note 34 , at 24.

49 Cf. Ziller, supra, note 8.

50 Same in Hofmann, Schneider, Ziller, supra, note 7, draft model rules for the EU APA, including six sections, one of which specifically on contractual relations.

51 Cf. Marko Šikić, Pravna zaštita od šutnje uprave prema novom Zakonu o općem upravnom postupku [Legal protection from administrative silence by new APA], in Modernizacija Općeg Upravnog Postupka i Javne Uprave u Hrvatskoj [Modernization of General Administrative Procedure and Public Administration in Croatia], 191, 197 (Ivan Koprić \& Vedran Đulabić eds., 2009).

52 Koprić, supra, note 34, at 46; cf. Kovač \& Remic, supra, note 49, at 22.

53 E.g. Koprić, supra, note 34 at 16, 27-28; Kovač, supra, note 15, at 26-32.

54 Koprić, supra, note 34, at 26-27; Kovač, supra, note 15, at 35-40.

55 More in Auburn, Moffett, Sharland, supra, note 41, at 236; more for Eastern Europe in Sever, Rakar, Kovač, supra, note 5.

56 Generally see in Statskontoret, supra, note 4; Rusch, supra, note 3; 
Hofmann, Schneider, Ziller, supra, note 7.

$57 C f$. Schwarze, supra, note 4.

58 Auburn, Moffett, Sharland, supra, note 41, at 110.

59 Ziller, supra, note 8 , at 5 .

60 The EU Code, supra, note 26, on legitimate expectation, consistency, courtesy, etc., and Hofmann, Schneider, Ziller, supra, note 7, referring to examples of service principle in Sweden or Spain.

61 See more on developmental steps in general in Barnes, supra, note 15, at 342, for Eastern Europe in William N. Dunn, Katarina Staronova and Sergei Pushkarev (eds.), Implementation: The Missing Link in Public

Administration Reform in Central and Eastern Europe (2006); Rusch, supra, note 3, and Kovač, supra, note 15. On strategic efforts in Slovenia Kovač \& Remic, supra, note 49, and in Croatia Koprić \& Đulabić, supra, note 34 .

62 Such as the ambivalence between parties and superiors. More in Kovač, supra, note 15 , at 55 .

63 Cf. Pavčnik, supra, note 12, at 246-247.

64 CoE, supra, note 27, i.e. $\operatorname{Rec}(2010) 3$.

65 Hofmann, Schneider, Ziller, supra, note 7, draft model rules for EU APA, dedicating one of six chapters to (inter-) administrative information management.

66 Compare with suggestions in Ziller, supra, note 3 (general); Kovač \& Remic, supra, note 49, at 22-23 (for Slovenia); Koprić, supra, note 34 (for Croatia).

67 See Koprić \& Đulabić, supra, note 34 at 11 et seq. on efforts to codify shorter laws in Croatia also by this approach.

(c) Boom juridisch 